\title{
Influenza Virus Infection of the Murine Uterus: A New Model for Antiviral Immunity in the Female Reproductive Tract
}

\author{
KATHRYN B. RENEGAR, ${ }^{1-4}$ ALAN MENGE, ${ }^{5}$ and JIRI MESTECKY ${ }^{1}$
}

\begin{abstract}
Secretory IgA (S-IgA) mediates local immunity to influenza virus in the murine upper respiratory tract and may play an important role in local immunity to various microorganisms in the female reproductive tract as well. Although the presence of IgA in cervicovaginal or uterine secretions has been correlated with immunity to a number of pathogens, there has been no direct demonstration of the mediation of uterine antiviral immunity by S-IgA. Influenza virus, although not a normal pathogen of the reproductive tract, was used to develop a model for the investigation of mucosal immunity in the uterus. PR8 (H1N1) influenza virus injected into the ovarian bursa of BALB/c mice grew well, with peak titers between days 3 and 5. Intravenous injection of polymeric IgA anti-influenza virus monoclonal antibody before or $30 \mathrm{~min}$ after viral challenge protected mice against viral infection. We believe this work to be the first direct demonstration of S-IgA-mediated antiviral uterine immunity. It provides a model for further investigation of immunity in the female reproductive tract.
\end{abstract}

\section{INTRODUCTION}

$\mathbf{S}^{\mathrm{s}}$ ECRETORY IgA (S-IgA), the major immunoglobulin isotype present at mucosal surfaces, is an important factor in local immunity $(20,35)$. S-IgA is derived from the $\mathrm{J}$ chain-containing polymeric $\operatorname{Ig} \mathrm{A}$ (pIgA) produced by plasma cells, which are found in large numbers in secretory glands and in the lamina propria of mucosal tissues $(11,20)$. Polymeric $\operatorname{IgA}$, present in the interstitial fluid bathing the basolateral surfaces of the mucosal epithelial cells, is transported through these cells by the transmembrane polymeric immunoglobulin receptor (pIgR), which binds to the $\operatorname{PIgA}$ molecule and carries it from the basolateral to the apical cell surface (12). There the receptor is cleaved, releasing the S-IgA molecule containing a large portion of the bound pIgR, known as secretory component (SC), into the mucosal secretions $(4,20)$.

The majority of IgA-positive plasma cells in mucosal tissues migrate there from IgA-inductive sites such as the gutassociated lymphoid tissue (GALT) and the bronchus-associated lymphoid tissue (BALT) (20). Stimulation of these IgA-inductive sites by antigens results in dissemination of specific IgA-producing cells to effector sites throughout the mucosal tissues $(9,19,25,44)$, leading to the concept of a common mucosal immune system (20).

The female reproductive tract is an integral part of this common mucosal system $(5,6,19)$. Immunization of the

\footnotetext{
${ }^{1}$ Department of Microbiology, University of Alabama at Birmingham, Birmingham, Alabama.

${ }^{2}$ Department of Comparative Medicine, University of Alabama at Birmingham, Birmingham, Alabama.

${ }^{3}$ Department of Surgery, University of Tennessee at Memphis, Memphis, Tennessee.

${ }^{4}$ Present address: 131 Fraker Road, Buffalo, Missouri.

${ }^{5}$ Department of Obstetrics and Gynecology, University of Michigan, Ann Arbor, Michigan.
} 
respiratory tract with liposomes supplemented with influenza viral hemagglutinin, for example, stimulates an IgA response in the murine uterus $(9,44)$. There are numerous studies correlating S-IgA production in the female reproductive tract with immunity $(1,4,7,10,14-17$, 21-23,25,27,36,43); however, a role for $\mathrm{S}-\mathrm{IgA}$ in protection of the female reproductive tract against viral infection has not been directly demonstrated.

In mice, plasma-derived pIgA can protect the upper respiratory tract from viral infection, as the passive transfer of nasal immunity to influenza virus has been accomplished via the intravenous injection of pIgA anti-influenza virus monoclonal antibody (mAb) $(29,30,32,33)$. Influenza virus replicates in fetal urogenital tissue from ferrets (40), guinea pigs (39), and humans (34), as well as in organ cultures of human and simian urogenital tissues and in human endometrial cell lines $(2,34)$. In the work described in this paper, we investigated in a murine model whether the uterus might support the growth of influenza virus and whether uterine immunity might then be evaluated by the passive transfer of pIgA anti-influenza virus mAb.

\section{MATERIALS AND METHODS}

\section{Animals}

Four- to 6-week-old female BALB/c mice for experimental protocols or retired breeder female mice for ascites production were obtained from Charles River Breeding Laboratories (Wilmington, MA) and maintained in an Association for the Assessment and Accreditation of Laboratory Animal Care-accredited animal facility. Food and water were supplied ad libitum. Experimental protocols were approved by an institutional animal care and use committee.

\section{Monoclonal IgA}

Hybridoma H37-66-1, producing monoclonal pIgA specific for the $\mathrm{Sb}$ epitope of the hemagglutinin of PR8 (A/PR8/34) H1N1 influenza virus, was the generous gift of W. Gerhard (Wistar Institute, Philadelphia, PA) and was generated as previously described (37). Hybridoma Z-F11-15, producing a pIgA not reacting with influenza virus, was the gift of $\mathrm{Z}$. Moldoveanu (University of Alabama at Birmingham, Birmingham, AL). The hybridomas were propagated as ascitic tumors in retired breeder mice. Ascitic fluid was harvested, pooled, and stored at $-70^{\circ} \mathrm{C}$. Pooled H37-66-1 ascitic fluid contained pIgA at $8.6 \mathrm{mg} / \mathrm{mL}$ as determined by radial immunodiffusion assay (ICN ImmunoBiologicals, Lisle, IL); pooled Z-F1115 contained $5.7 \mathrm{mg} / \mathrm{mL}$ pIgA mAb. On the basis of the amount of background $\operatorname{IgA}$ present in several $\mathrm{IgG}$ ascites pools (radial immunodiffusion assay determination),
H37-66-1 pools contained less than 3\% nonspecific IgA antibody. Both sucrose gradient sedimentation (30) and ACA column chromatography (31) showed H37-66-1 pools to be composed of greater than $75 \%$ polymeric antibody forms. Sedimentation analysis of H-37-66-1 pIgA $\mathrm{mAb}$ collected from the nasotracheal lavages and bile of intravenously injected mice showed that the $\mathrm{mAb}$ retained its polymeric form on transport (30). Furthermore, H-37-66-1 injected intravenously into a Lewis rat and collected by bile duct cannulation acquired secretory component as it was removed from the circulation (31), indicating that it was a $\mathrm{J}$ chain-containing polymeric $\operatorname{Ig} \mathrm{A}$ and not simply an aggregate of monomeric IgA molecules.

\section{Virus}

A/PR8-Mt. Sinai (H1N1) influenza virus was the gift of W. Gerhard. To generate a pool, virus was grown in eggs, pooled, filtered through a $0.45-\mu \mathrm{m}$ pore size filter, aliquoted, and stored at $-70^{\circ} \mathrm{C}$. Viral growth was assayed in Madin-Darby canine kidney (MDCK) cells as described below and viral titers were calculated by the method of Reed and Muench (28). The $\log _{10}$ TCID $_{50}$ (50\% infectious dose in tissue culture) of the virus pool was 5.6.

\section{Uterine infection protocol}

Eight- to 10-week-old female BALB/c mice were anesthetized by intramuscular injection of a mixture of $1 \mathrm{mg}$ of ketamine plus $1 \mathrm{mg}$ of xylazine. A $2.5-\mathrm{cm}$ incision was made parallel and dorsal to the lumbar spine, the ovaries were exteriorized, and each ovarian bursa was injected with $2 \times 10^{2.5}$ TCID $_{50}$ of PR8 influenza virus (volume, $20 \mu \mathrm{L}$ ), using a 30-gauge needle. The surgical procedure was performed under a dissecting microscope. The incision was closed with 3-0 wire sutures to discourage gnawing of the healing wound. At various times postinfection, mice were killed (by intravenous injection of $30 \mathrm{mg}$ of xylazine) and the uterus was removed for assay. The uterus and uterine horns were flushed with $600 \mu \mathrm{L}$ of cold $\left(4^{\circ} \mathrm{C}\right)$ sterile phosphate-buffered saline (PBS) and the wash fluid was saved for viral assay. The washed uterus was then ground in $600 \mu \mathrm{L}$ of cold sterile PBS and centrifuged at $1000 \mathrm{rpm}$ to remove debris, and the supernatants were assayed for virus. To preserve viral viability, samples (washes and ground uterus supernatants) were not frozen but were kept on ice and assayed as described below within $1 \mathrm{~h}$.

\section{Viral assay}

A modification of the viral assay originally developed by Wyde et al. (47) and adapted by Bender et al. (3) was used. Viral samples were serially diluted (10-fold) in Dul- 
becco's modified Eagle's medium (DMEM) supplemented with amphotericin B $(2.5 \mu \mathrm{g} / \mathrm{mL}$; Sigma, St. Louis, MO), gentamicin (50 $\mu \mathrm{g} / \mathrm{mL} ;$ Sigma), and $10 \%$ fetal calf serum (FCS). Triplicate 100- $\mu \mathrm{L}$ samples of each dilution were placed into 96-well round-bottom tissue culture plates. To each well was added $100 \mu \mathrm{L}$ of a suspension of MDCK cells $\left(2 \times 10^{5}\right.$ cells $\left./ \mathrm{mL}\right)$ in supplemented DMEM-10\% FCS. The plates were incubated for $24 \mathrm{~h}$ at $34^{\circ} \mathrm{C}$ in $5 \% \mathrm{CO}_{2}$. The culture fluid was removed and replaced with DMEM (150 $\mu \mathrm{L} /$ well) containing amphotericin B $(2.5 \mu \mathrm{g} / \mathrm{mL})$, gentamicin $(50 \mu \mathrm{g} / \mathrm{mL})$, and trypsin $(2 \mu \mathrm{g} / \mathrm{mL})$ (DMEM-trypsin). The plates were then incubated for $4 \mathrm{~d}$ at $34^{\circ} \mathrm{C}$ in $5 \% \mathrm{CO}_{2}$. Assay for viral growth was by hemagglutination (HA). To each well was added $50 \mu \mathrm{L}$ of a $0.5 \%$ suspension of chicken red blood cells (CRBCs). HA was read after $1-2 \mathrm{~h}$ in the cold. Viral titers were calculated by the method of Reed and Muench (28).

\section{Histology}

Uteri were removed from killed normal mice or from mice infected intrabursally $96 \mathrm{~h}$ previously with influenza virus. One horn of each uterus was processed for light microscopy and one for scanning electron microscopy. For light microscopy, samples were fixed in $10 \%$ neutral buffered formalin, embedded in paraffin, cut into $2-\mu \mathrm{m}$ sections, and stained with hematoxylin and eosin. For electron microscopy, samples were fixed in glutaraldehyde-cacodylate buffer $(2.5 \%$ glutaraldehyde dissolved in $0.1 \mathrm{M}$ sodium cacodylate buffer) and stored at $4^{\circ} \mathrm{C}$ until processed. For processing, samples were postfixed with $1 \%$ osmium tetroxide, dehydrated with successive transfers to $70 \%, 90 \%$, and absolute ethanol, and dried in a desiccator after treatment with hexamethyldisilane. The samples were then mounted and coated to a thickness of $80 \mathrm{~nm}$ with gold-palladium.

\section{Protection protocol}

Female BALB/c mice were injected intravenously via the tail vein with $200 \mu \mathrm{L}$ of H66-37-1 or Z-F11-15 ascites mixed with $200 \mu \mathrm{L}$ of saline. The ascites was centrifuged before injection to preclude embolus formation. Four hours later, the mice were anesthetized and infected as previously described. In some cases, mice were infected first and injected with H66-37-1, 30 min later. Mice were killed at various times postinfection and their uteri were assayed for viral growth as described.

\section{Antibody transport protocol}

Twelve 8- to 10-week-old female BALB/c mice were injected intravenously via the tail vein with $200 \mu \mathrm{L}$ of pIgA anti-influenza mAb-containing ascitic fluid that had been centrifuged to preclude embolus formation and mixed with $200 \mu \mathrm{L}$ of saline (dose of $1700 \mu \mathrm{g}$ of pIgA per mouse). At 2, 4, and $8 \mathrm{~h}$ postinjection four mice were injected intravenously with $30 \mathrm{mg}$ of xylazine. The chest was opened and the mouse was perfused with PBS to minimize contamination of uterine lavages with blood contained within the vascular system. An 18-gauge needle attached to a $60-\mathrm{mL}$ syringe containing $50 \mathrm{~mL}$ of PBS was placed in the left ventricle of the heart and clamped in place with a hemostat. An incision was made in the right ventricle to allow drainage and the circulatory system was perfused with the PBS. Perfusion was monitored by observation of the liver, which became clay-colored as blood was flushed from the system. The intact uterus was then clamped proximal to the cervix with a curved hemostat and excised with the cut immediately proximal to the cervix, its exterior rinsed with PBS to remove any trace of blood, and the interior lavaged with $600 \mu \mathrm{L}$ of PBS, which was flushed once through each horn and collected in a microcentrifuge tube as it drained from the distal end of the uterus.

\section{Antibody titer determination}

Uterine wash pIgA anti-influenza virus mAb titers were determined by a modification of the enzyme-linked immunosorbent assay (ELISA) previously described (32). PR8 influenza vaccine (the gift of F. Brandon, Parke, Davis, and Co., Rochester, MI) was dried onto 96well flat-bottom enzyme immunoassay (EIA) microtiter trays (EIA II Plus microtitration plates; MP Biomedicals, Solon, $\mathrm{OH}$ ). Unreacted sites were blocked overnight at $4^{\circ} \mathrm{C}$ with PBS-Tween containing $1 \%$ bovine serum albumin (BSA) for ELISA diluent applications (Sigma) and $1 \%$ normal rabbit serum (NRS). All antibodies were diluted in PBS-Tween containing $1 \%$ bovine serum albumin (BSA) and 1\% NRS and PBS-Tween was used for all plate washes. After overnight blocking, the plates were washed, uterine wash samples were added in triplicate, and the trays were incubated overnight at $4^{\circ} \mathrm{C}$. The plates were washed, and the second and third antibodies were added and incubated for $1.5 \mathrm{~h}$ at room temperature. Affinity-purified goat anti-mouse IgA was the second antibody, and the final antibody was rabbit anti-goat IgG coupled to alkaline phosphatase (NRS and both antibodies were obtained from Sigma). Reaction with the substrate p-nitrophenyl phosphate (Sigma) produced a yellow color that was read at $405 \mathrm{~nm}$ as an end-point ELISA on a Spectromax 190 ELISA reader (Molecular Devices, Sunnyvale, CA). Titers were calculated from sample dilutions relative to a dilution of the standard pIgA mAb. The titer is defined as the ratio of the dilution of sample required to give a specific ELISA optical density (OD) to the dilution of the standard required to give the same OD (parallel line method), expressed as a percentage. For example, a sample with a titer of $1 \times 10^{-3}$ contains $0.001 \%$ 




FIG. 1. Growth of influenza virus in the murine uterus. Mice were infected via injection of the ovarian bursa with $2 \times$ $10^{2.5}$ TCID $_{50}$ of PR8 influenza virus. Mice were killed and uteri were assayed for virus in uterine washes (solid squares) or ground uterus (open squares) at various times after infection. Each point represents four to six animals.

as much antibody as the ascites standard. The ascites pool used as the standard contained an $8.6-\mathrm{mg} / \mathrm{mL}$ concentration of pIgA anti-influenza virus mAb. Standard wells containing known concentrations of $\mathrm{mAb}$ from this pool were included on each ELISA plate so that the concentration of transported $\mathrm{mAb}$ in the uterine lavages could be readily determined.

Because binding of antibody to the influenza vaccinecoated plates requires antibody specificity, this ELISA detects only the intravenously injected influenza virusspecific $\mathrm{mAb}$.

\section{Statistics}

All data are expressed as means \pm SD. Nonparametric (Mann-Whitney) and parametric (analysis of variance [ANOVA] and Fisher's protected least significant difference [PLSD]) analyses were carried out on a Macintosh Performa using StatView 4.2 (SAS Institute, Cary, NC) software.

\section{Graphics}

Figures were generated with CA-Cricket Graph III software (CA, Islandia, NY) on an Apple iBook (Apple Computer, Cupertino, CA). Photomicrographs were also processed on the Apple iBook, using Adobe Photoshop 7.0 software.

\section{RESULTS}

\section{Influenza virus grows in the murine uterus}

Growth of PR8 influenza virus in the murine uterus is shown in Fig. 1. Similar viral titers $\left(10^{4}\right.$ to $\left.10^{5} \mathrm{TCID}_{50}\right)$ were reached in both uterine washes and ground uterus. The highest virus titers occurred 3 to $5 \mathrm{~d}$ after infection. This finding mimicks the growth pattern seen in the nose, trachea, and lungs when the influenza virus is inoculated into the noses of awake nonimmune mice (24).

Histologic studies were performed $96 \mathrm{~h}$ after viral infection, at the time of peak viral titer. By light microscopy, the most notable pathology associated with viral infection was the loss of cilia from the epithelial cells



FIG. 2. Light microscopy of the murine oviduct. Mice were infected via injection of the ovarian bursa with $2 \times 10^{2.5}$ TCID $_{50}$ of PR8 influenza virus. Ninety-six hours postinfection, infected and noninfected control animals were killed and the uterus was removed for light and scanning electron microscopy analysis. Normal murine oviduct is lined by ciliated cells with tapered tips [arrow in (A)]. After influenza infection, the cilia were lost and the epithelial cells lining the interior of the ovarian bursa were necrotic with condensed, pycnotic nuclei and indistinct cellular outlines. Areas of desquamation [arrows in (B)] were evident. Original magnification: $\times 400$. 
lining the oviduct (Fig. 2B). Neither the uterus nor the oviduct displayed the extensive desquamation seen in the tracheas of influenza virus-infected mice $(13,48)$; however, the 96-h time frame may have been too short for the full pathologic effects of the infection to develop, The ciliated columnar epithelial cells lining the oviduct of infected mice appeared necrotic, with pycnotic nuclei and indistinct cellular outlines. Areas of limited desquamation were present and cells within the submucosa were farther apart than those in the noninfected tissue, suggesting the presence of interstitial edema. The uterine epithelium showed similar pathology, with pycnotic nuclei, indistinct cellular architecture, and minimal desquamation. Scanning electron microscopy (Fig. 3) confirmed the clipping of the cilia of the oviduct. In normal mice, the oviduct was characterized by both short microvilli and longer cilia with slightly rounded tapered tips (Fig. $3 \mathrm{~A})$. In infected mice, both the microvilli and the cilia were severely blunted. The cilia were shortened and deformed (Fig. 3B) and, in some cases, adhered to each other (Fig. 3C).

\section{Influenza virus-specific pIgA is transported into the uterus}

To demonstrate that intravenously administered $\mathrm{pIgA}$ can be transported into the uterus, a single intravenous injection of $1700 \mu \mathrm{g}$ of pIgA anti-influenza virus mAb (the dose shown to saturate the murine transport system [30,32]) was administered to 12 mice. Four mice were killed 2, 4, or $8 \mathrm{~h}$ postinjection and uterine lavages were performed to harvest the transported antibody. Passively administered $\mathrm{pIgA}$ antibody was, as previously reported in the rat, transported into murine uterine secretions (46). The pattern (Fig. 4A and B) resembles that seen in nasal lavages of pIgA-injected mice (32), with peak transport of $2.62 \pm 3.87 \mu \mathrm{g}$ (or $0.154 \%$ of the injected dose) of pIgA anti-influenza mAb per uterus reached by $4 \mathrm{~h}$ postinjection.

\section{Influenza virus-specific pIgA protects the uterus from infection}

H66-37-1 is a $\operatorname{pIgA}$ mAb directed toward the $\mathrm{H} 1$ hemagglutinin of the A/PR8 influenza virus. We have shown that it can be transported into the bile of Lewis rats, acquiring SC in the process (31), and into murine nasal secretions, presumably also by the pIgR, and that the transported antibody retains its polymeric form and can prevent infection of the murine nose by influenza virus $(30,32)$. To determine whether this antibody can also protect the murine uterus from viral infection, female BALB/c mice were injected intravenously with $1700 \mu \mathrm{g}$ of $\mathrm{pIgA}$ anti-influenza virus mAb or with saline $4 \mathrm{~h}$ before injection of virus into the ovarian bursa. Viral growth in passively immunized animals was determined 1,2, and $3 \mathrm{~d}$ after viral infection (Table 1). On days 1 and 2 all the mice injected with influenza virusspecific $\mathrm{pIgA} \mathrm{mAb}$ were protected from viral infection, regardless of whether uterine washes or ground uteri were assayed. On day 3, 9 of 12 uterine washes and 7 of 8 ground uteri from H66-injected mice showed no viral infection (Table 1). Those influenza virus-specific pIgA mAb-injected mice that shed virus (Table 2) did so at a reduced titer relative to saline-injected mice whether in uterine washes $(p<0.001)$ or ground uterus $(p<0.05)$. Injection of Z-F11-15, a pIgA of unrelated specificity, did not protect against influenza virus infection.

Under the standard protocol, mice were injected first with antibody, and then challenged with virus. To rule out the possibility that blood with a high titer of influenza virus-specific pIgA leaking into the ovarian bursa via the

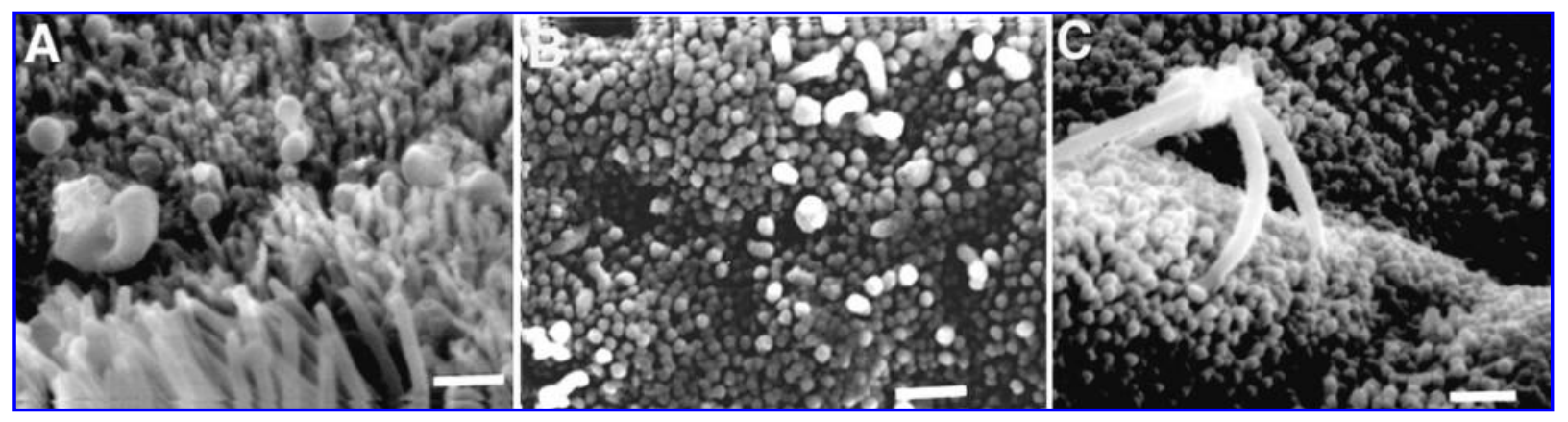

FIG. 3. Scanning electron photomicrographs of the murine oviduct. Mice were infected via injection of the ovarian bursa with $2 \times 10^{2.5} \mathrm{TCID}_{50}$ of PR8 influenza virus. Ninety-six hours postinfection, infected and noninfected control animals were killed and the uterus was removed for light and scanning electron microscopy analysis. Epithelial cells lining the normal murine oviduct (A) bear both long cilia and shorter microvilli. These cilia, like those of the respiratory tract, have tapered tips. In the influenza virus-infected oviduct, microvilli and cilia are short and blunted (B) and, in some cases, form clumps (C). Original magnification: $\times 10,000$. Scale bars: $1 \mu \mathrm{m}$. 
small puncture at the inoculation site was neutralizing the virus before initial cellular infection, mice were first infected with influenza virus, and then injected with antibody 30 min later, allowing the initial stage of viral infection to occur before antibody injection. Mice treated in this manner were still protected (Table 2), suggesting that protection was due to antibody transported into the uterus, preventing further rounds of viral replication, and not to antibody-containing blood leaking into the ovarian bursa at the time of viral inoculation.
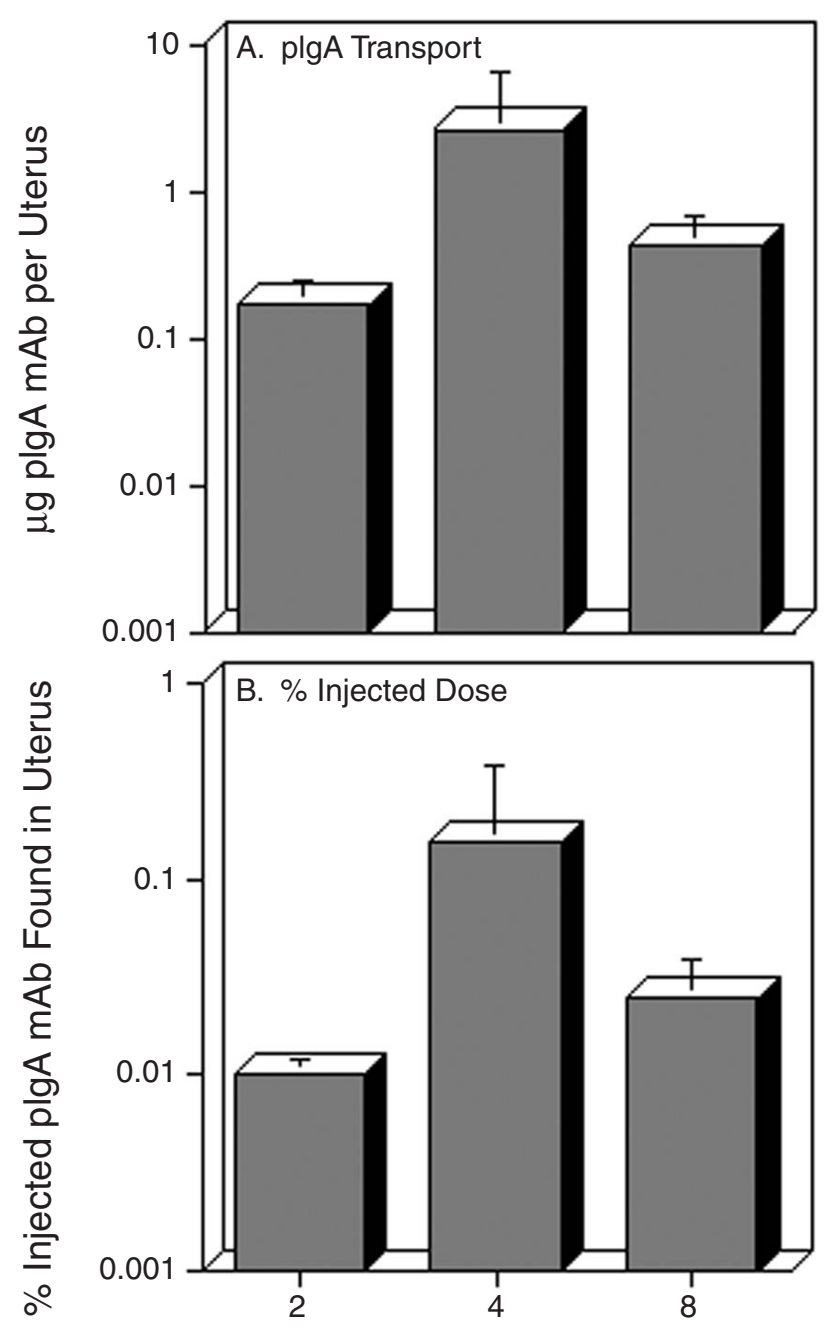

Hours Post-Injection

FIG. 4. Transport of $\mathrm{pIgA}$ anti-influenza virus $\mathrm{mAb}$ into the murine uterus. Mice were injected intravenously with 1700 $\mu \mathrm{g}$ of pIgA anti-influenza virus mAb. At various times postinjection, mice were killed and the total amount of mAb (A) recovered per uterus was determined by ELISA analysis. The percentage of the injected dose of pIgA anti-influenza virus $\mathrm{mAb}$ recovered per uterus is shown in $(\mathbf{B}) . n=4$ mice per time point.

\section{DISCUSSION}

Passive immunization studies of the murine respiratory and gastrointestinal tracts have shown that $\mathrm{S}-\operatorname{IgA}$ alone is able to mediate local immunity against viruses $(18,32,41,42)$ and bacteria $(8,45)$. The genitourinary tract is an important port of entry for pathogenic viruses and microorganisms. Involvement of S-IgA in uterine or cervicovaginal immunity has been implied by a number of studies correlating antibody levels with protection and/or recovery from infection $(1,7,14,17,21-23,25,27,29,36$, 43 ) and by two studies in which the continuous secretion of a high level of pIgA anti-Chlamydia mAb from a "backpack" tumor was able to slow the progress of chlamydial infection into the uterus after vaginal challenge in the mouse $(8,26)$; however, there are no studies directly demonstrating the role of S-IgA in antiviral immunity in the female reproductive tract, possibly because of the complexity of the immune response to two of the major pathogens of interest, that is, the human immunodeficiency virus and herpes simplex virus type 2 viruses, and the difficulty in propagating these pathogens in the murine model. The demonstration of this immunity requires, first, a model for the consistent infection of the uterus and, second, an agent-specific pIgA capable of neutralizing the growth of the infective agent and of being transported to its potential site of action in vivo by the pIgR. Herein, we have demonstrated that the influenza virus model meets these requirements.

Although influenza virus is not a normal pathogen of the reproductive tract, the influenza viral infection model is one of the best characterized as far as antibody selective transport, isotype involvement, viral neutralization, and in vivo protection from viral infection are concerned. In addition, mice are easily infected with the mouseadapted PR8 influenza virus, the virus is easy to propagate and assay in vitro, its cellular receptors are well known, and it is safe to handle under general laboratory conditions

Sweet et al. (40) showed that influenza virus grew in the oviduct of fetal ferrets. Additional studies with guinea pigs (39) and human fetal tissue (34) further demonstrated the growth of influenza virus in genitourinary tissues. We found that PR8 influenza virus, when injected into the ovarian bursa, was also capable of growing in the mature murine uterus. Infection was consistent and reproducible: virus could be detected in uterine secretions (uterine washes) or in uterine tissue in comparable amounts (Fig. 1). Pathologic changes associated with viral infection were most severe in the ciliated cells of the oviducts (Figs. 2 and 3), which underwent necrosis, losing their cilia in the process. Areas of desquamation were noted, as well as interstitial edema within the oviduct. The uterine epithelium showed similar, although not as 
Table 1. Effect of Pretreatment with Intravenous piga Anti-Influenza Virus mAb on Intrauterine Viral Multiplication in Mice Infected via the Ovarian Bursa with Influenza Virus

\begin{tabular}{|c|c|c|c|c|}
\hline \multirow[b]{3}{*}{$\begin{array}{l}\text { Day } \\
\text { post } \\
\text { infection }\end{array}$} & \multicolumn{2}{|c|}{ Uterine washes } & \multicolumn{2}{|c|}{ Ground uterus } \\
\hline & \multicolumn{2}{|c|}{ Mouse treatment } & \multicolumn{2}{|c|}{ Mouse treatment } \\
\hline & $\begin{array}{c}\text { Intravenous saline } \\
\text { (no. mice } \\
\text { shedding virus/ } \\
\text { total no. infected } \\
\text { mice) }\end{array}$ & $\begin{array}{c}\text { Intravenous pigA } \\
\text { (no. mice } \\
\text { shedding virus/ } \\
\text { total no. infected } \\
\text { mice) }\end{array}$ & $\begin{array}{c}\text { Intravenous saline } \\
\text { (no. mice } \\
\text { shedding virus/ } \\
\text { total no. infected } \\
\text { mice) }\end{array}$ & $\begin{array}{c}\text { Intravenous pigA } \\
\text { (no. mice } \\
\text { shedding virus/ } \\
\text { total no. infected } \\
\text { mice) }\end{array}$ \\
\hline 1 & $3 / 3$ & $0 / 2(p<0.05)^{\mathrm{a}}$ & $3 / 3$ & $0 / 2(p<0.05)$ \\
\hline 2 & $5 / 6$ & $0 / 6(p<0.01)$ & $6 / 6$ & $0 / 6(p<0.01)$ \\
\hline 3 & $6 / 6$ & $3 / 12(p<0.01)$ & $6 / 6$ & $1 / 8(p<0.002)$ \\
\hline
\end{tabular}

${ }^{a}$ Mann-Whitney nonparametric analysis, saline versus $\mathrm{pIgA}$.

severe, pathology. The viral pathology was not dissimilar to that seen in influenza viral infection of the murine respiratory tract, where the ciliated cells of the trachea undergo complete desquamation $(13,48)$; while the ciliated cells of the nose show blunting of the ciliary tips (33).

Renegar and Small (32) showed that the anti-influenza virus pIgA mAb used in this study could be selectively transported into nasal secretions relative to monomeric immunoglobulin, that the time of peak transport was $4 \mathrm{~h}$ after injection, and that transported antibody was able to protect the nose against influenza viral infection. In this paper, we show that intravenously injected pIgA antiinfluenza virus $\mathrm{mAb}$ is also transported into uterine secretions and that peak transport, like that seen in the respiratory tract, occurs $4 \mathrm{~h}$ postinjection. The $\mathrm{pIgA}$ antiinfluenza virus $\mathrm{mAb}$ pool contained approximately $25 \%$ monomeric IgA, and therefore we cannot exclude the possibility that monomeric influenza-specific IgA mAb contributed to the observed uterine protection; however, because the polymeric form of pIgA comprised at least $75 \%$ of the $\mathrm{pIgA}$ pool used for injection and because any monomeric $\operatorname{IgA}$ included in the $\mathrm{mAb}$ dose would have been diluted in the normal intravascular monomeric immunoglobulin pool, we believe that protection in our model was due to S-IgA transported into the uterus by the pIgR. Sullivan and Wira (38) reported that uterine tissues were saturated with pIgA antibody by 2 to $4 \mathrm{~h}$ postinjection and that pIgR-mediated transport was seen by 4 $h$ postinjection in estrogen-treated ovariectomized female rats. This is consistent with the 4-h postinjection IgA peak we observed. We have shown $(30,32)$ that in mice the percent injected dose of monomeric immunoglobulin

Table 2. Effect of Pre- or Postviral Challenge with Intravenous pIgA Anti-Influenza Virus mAb on 72-h Postinfection Viral Titers in Mice Infected with Influenza Virus VIA THE OVARIAN BURSA ${ }^{\mathrm{a}}$

\begin{tabular}{|c|c|c|c|c|}
\hline \multirow[b]{2}{*}{$\begin{array}{l}\text { Mouse } \\
\text { treatment }\end{array}$} & \multicolumn{2}{|c|}{ Uterine washes } & \multicolumn{2}{|c|}{ Ground uterus } \\
\hline & $\begin{array}{l}\log _{10} \text { titer } \\
\text { virus in } \\
\text { washes }\end{array}$ & $\begin{array}{c}\text { No. mice shedding } \\
\text { virus/total no. } \\
\text { mice infected }\end{array}$ & $\begin{array}{c}\log _{10} \text { titer } \\
\text { virus in } \\
\text { tissue }\end{array}$ & $\begin{array}{c}\text { No. mice shedding } \\
\text { virus/total no. } \\
\text { mice infected }\end{array}$ \\
\hline A. Intravenous saline $\rightarrow$ virus & $4.77 \pm 5.2$ & $8 / 8$ & $5.95 \pm 6.4$ & $7 / 7$ \\
\hline B. H66 pIgA $\rightarrow$ virus & $0.15 \pm 0.28$ & $1 / 8$ & $0.57 \pm 0.12$ & $1 / 8$ \\
\hline C. $\mathrm{ZF} 11 \mathrm{pIgA} \rightarrow$ virus & $4^{\mathrm{b}}$ & $5 / 5$ & $4^{\mathrm{b}}$ & $5 / 5$ \\
\hline D. Virus $\rightarrow$ H66 pIgA & 0 & $0 / 2$ & 0 & $0 / 2$ \\
\hline
\end{tabular}

aParametric statistical analysis (ANOVA and Fisher's PLSD post hoc): Uterine washes: A vs. B, $p<0.001$; B vs . C, $p<0.0001$; A vs. D, $p<0.02$; one mouse in group A with excessively high viral titers was excluded from statistical calculations. Ground uterus: A vs. B, $p<0.05$; B vs. C, $p<0.0001$; C vs. D, $p<0.0001$; one mouse in group A with excessively high viral titers was excluded from statistical calculations. Nonparametric statistical analysis (Mann-Whitney): Uterine washes: A vs. B, $p<0.005 ; \mathrm{A}$ vs. D, $p<0.04$; B vs. C, $p<0.02$. Ground uterus: A vs. B, $p<0.005$; A vs. D, $p<0.05$; B vs. C, $p<0.02$.

${ }^{\mathrm{b}}$ Titers of all mice were in excess of 3.5 
reaching the secretions remains relatively constant with increasing time postinjection, whereas the percent injected dose of pIgA peaks and then drops as hepatobiliary pIgR rapidly removes polymeric immunoglobulins from the circulation. In our uterine transport model (Fig. $4 \mathrm{~A}$ and $\mathrm{B})$, both the uterine anti-influenza virus $\mathrm{mAb}$ titer and the percent injected dose peaked $4 \mathrm{~h}$ postinjection. After this peak, both transport parameters fell to the 2-h level. This pattern is consistent with transport of pIgA into the uterus by the pIgR. Furthermore, selective transport into the murine uterus of $\mathrm{pIgA}$ relative to monomeric immunoglobulin has been shown to occur (selective transport index $4 \mathrm{~h}$ after antibody injection, $6.2 \pm 5.2$; K.B. Renegar, unpublished data), indicating that pIgRmediated uterine transport of pIgA takes place. Hence, we believe that $\mathrm{S}$-IgA mediated the uterine immunity in our model.

We investigated uterine immunity using the same virus-antibody system previously used to study nasal immunity. As with protection of the respiratory tract, a single dose of anti-influenza virus pIgA mAb administered $4 \mathrm{~h}$ before viral challenge was able to protect the murine oviducts and uterus from influenza virus infection (Tables 1 and 2). Protection required specific antibody and occurred regardless of the order in which antibody and virus were administered. Because monomeric immunoglobulins readily enter uterine secretions, it is likely that not only pIgR-transported pIgA but also plasma influenza virus-specific $\mathrm{IgG} \mathrm{mAb}$ can confer protection on the uterus. Further studies are required to delineate more completely the roles of IgA and IgG in uterine immunity.

In conclusion, we have shown that influenza virus will grow in the murine uterus, providing a model for the study of uterine immunity. Intravenously injected influenza virus-specific pIgA mAb was transported into the uterus and protected the uterus against viral infection. This is the first direct demonstration of the prevention of uterine viral infection by $\operatorname{pIgA}$ and we believe that it is also the first direct demonstration of the mediation of antiviral immunity in the uterus by $\mathrm{S}-\operatorname{IgA}$. This model should be useful in delineating the relative roles of $\operatorname{IgA}$ and $\mathrm{IgG}$ in uterine immunity; moreover, it should prove a valuable tool in determining the effect of hormonal variation on antibody-mediated uterine immunity.

\section{ACKNOWLEDGMENTS}

This work was supported by NIH grants AI-10854 and AI-18745 (to UAB) and by NIH grant AI-01359 (to UTMemphis). At UAB, K.B.R. was supported by National Heart, Blood, and Lung Institute Training Grant HL07553.

\section{REFERENCES}

1. Akagi T, Kawamura M, Ueno M, Hiraishi K, Adachi M, Serizawa T, Akashi M, and Baba M: Mucosal immunization with inactivated HIV-1-capturing nanospheres induces a significant HIV-1 specific vaginal antibody response in mice. J Med Virol 2003;69:163-172.

2. Ball JM, Moldoveanu Z, Melsen LR, Kozlowski PA, Jackson S, Mulligan MJ, Mestecky JF, and Compans RW: A polarized human endometrial cell lline that binds and transports polymeric IgA. In Vitro Cell Dev Biol Anim 1995;31:196-206.

3. Bender BS, Croghan T, Zhang L, and Small PA Jr: Transgenic mice lacking class I major histocompatibility complex-restricted $\mathrm{T}$ cells have delayed viral clearance and increased mortality after influenza virus challenge. J Exp Med 1992;175:1143-1145.

4. Boyaka PN, McGhee JR, Czerkinsky C, and Mestecky J: Mucosal vaccines: An overview. In Mestecky J, Bienenstock J, Lamm ME, Mayer L, McGhee JR, and Strober W, eds. Mucosal Immunology, 3rd ed. Elsevier Academic Press, Burlington, MA, 2005, pp. 855-872.

5. Briese V, Bergman KC, Pohl WD, Noack R, Tischner H, and Straube W: Occurence of antibodies against influenza viruses in the female genital tract of mice following oral immunization. Zentralbl Gynakol 1986;108:246-250.

6. Briese V, Pohl WD, K Noack, Tischner H, and Waldman RH: Influenza-specific antibodies in the female genital tract of mice after oral administration of live influenza vaccine. Arch Gynecol 1987;240:153-157.

7. Brunham RC, Kuo C-C, Cles L, and Holmes KK: Correlation of host immune response with quantitative recovery of Chlamydia trachomatis from the human endocervix. Infect Immun 1983;39:1491-1494.

8. Cotter TW, Meng Q, Shen ZL, Zhang YX, Su H, and Caldwell HD: Protective efficacy of major outer membrane protein-specific immunoglobulin A (IgA) and IgG monoclonal antibodies in a murine model of Chlamydia trachomatis genital tract infection. Infect Immun 1995;63:4704-4714.

9. de Haan A, Renegar KB, Small PA Jr, and Wilschut J: Induction of a secretory IgA response in the female urogenital tract by immunization of the lungs with liposome-supplemented viral subunit antigen. Vaccine 1995;13:623616.

10. Head JR, and Billingham RE: Concerning the immunology of the uterus. Am J Reprod Immunol Microbiol 1986;10: 76-81.

11. Johansen FE, Braathen R, and Brandtzaeg P: The J chain is essential for polymeric Ig receptor-mediated epithelial transport of IgA. J Immunol 2001;167:5185-5192.

12. Kaetzel CS, and Mostov K: Immunoglobulin transport and the polymeric immunoglobulin receptor. In Mestecky J, Bienenstock J, Lamm ME, Mayer L, McGhee JR, and Strober 
W, eds. Mucosal Immunology, 3rd ed. Elsevier Academic Press, Burlington, MA, 2005, pp. 211-250.

13. Kris RM, Yetter RA, Cogliano R, Ramphal R, and Small PA Jr: Passive serum antibody causes temporary recovery from influenza virus infection of the nose, trachea, and lung of nude mice. Immunology 1988;63:349-353.

14. Kwant A, and Rosenthal KL: Intravaginal immunization with viral subunit protein plus $\mathrm{CpG}$ oligodeoxynucleotides induces protective immunity against HSV-2. Vaccine 2004;22:3098-3104.

15. Lamont HC, Semine DZ, Leveille C, and Nichols RL: Immunity to vaginal reinfection in female guinea pigs infected sexually with Chlamydia of guinea pig inclusion conjunctivitis. Infect Immun 1978;19:807-813.

16. LeBlanc M, Ward L, Tran T, and Widders P: Identification and opsonic activity of immunoglobulins recognizing Streptococcus zooepidemicus antigens in uterine fluids of mares. J Reprod Fertil Suppl 1991;44:289-296.

17. Lu YS, Pakes SP, Massey L, and Stefanu C: A potassium thiocyanate extract vaccine prepared from Pasteurella multocida protects rabbits against homologous challenge. Infect Immun 1987;55:2967-2976.

18. Mazanec MB, Nedrud JG, and Lamm ME: Immunoglobulin A monoclonal antibodies protect against Sendai virus. J Virol 1987;61:2624-2626.

19. McDermott MR, and Bienenstock J: Evidence for a common mucosal immunologic system. I. Migration of B immunoblasts into intestinal, respiratory, and genital tissues. J Immunol 1979;122:1892-1898.

20. Mestecky J, and McGhee JR: Immunoglobulin A (IgA): Molecular and cellular interactions involved in IgA biosynthesis and immune response. Adv Immunol 1987;40: 153-245.

21. Mazzoli S, Trabaittoni D, Lo Caputo S, Piconi S, Ble C, Maecci F, Ruzzante S, Salvi A, Semplici F, Longhi R, et $a l .:$ HIV specific mucosal and cellular immunity in HIVseronegative partners of HIV-seropositive partners of HIVseropositive individuals. Nat Med 1997;3:1250-1257.

22. Morrison LA, Da Costa XJ, and Knipe DM: Influence of mucosal and parenteral immunization with a replicationdefective mutant of HSV-2 on immune responses and protection from genital challenge. Virology 1998;243:178187.

23. Muster T, Ferko B, Kilma A, Purtscher M, Trkola A, Schult P, Grassauer A, Engelhardt OG, Garcia-Sastre A, Palese P, et al: : Mucosal model of immunization against human immunodeficiency virus type 1 with a chimeric influenza virus. J Virol 1995;69:6678-6686.

24. Novak M, Moldoveanu Z, Shafer DP, Mestecky J, and Compans RW: Murine model for evaluation of protective immunity to influenza virus. Vaccine 1993;11:56-60.

25. Ogra PL, Okamoto Y, Freihorst J, LaScolea LJ Jr, and Merrick JM: Immunization of the gastrointestinal tract with bacterial and viral antigens: Implications in mucosal immunity. Immunol Invest 1989;18:559-570.

26. Pal S, Theodor I, Peterson EM, and de la Maza LM: Monoclonal immunoglobulin A antibody to the major outer membrane protein of the Chlamydia trachomatis mouse pneumonitis biovar protects mice against a chlamydial genital challenge. Vaccine 1997;15:575-582.

27. Parr EL, and Parr MB: Anti-bacterial IgA and IgG in mouse uterine luminal fluid, vaginal washings, and serum. $\mathrm{J}$ Reprod Immunol 1988;13:65-72.

28. Reed LJ, and Muench H: A simple method for estimating 50\% end points. Am J Hyg 1938;27:493-497.

29. Renegar KB: Passive immunization: Systemic and mucosal. In Mestecky J, Bienenstock J, Lamm ME, Mayer L, McGhee JR, and Strober W, eds. Mucosal Immunology, 3rd ed. Elsevier Academic Press, Burlington, MA, 2005, pp. 841-851.

30. Renegar KB: Transport of polymeric IgA into nasal secretions. In Renegar KB, Ph.D. dissertation: The Role of Secretory IgA in Murine Nasal Immunity. University of Florida, Gainesville, FL, 1990, pp. 16-53.

31. Renegar KB, Jackson GDF, and Mestecky J: In vitro comparison of the biologic activities of monoclonal monomeric $\operatorname{IgA}$, polymeric $\operatorname{IgA}$, and secretory $\operatorname{IgA}$. Immunol 1998;160:1219-1223.

32. Renegar KB, and Small PA Jr: Passive transfer of local immunity to influenza virus infection by IgA antibody. $\mathrm{J} \mathrm{Im-}$ munol 1991;146:1972-1978.

33. Renegar KB, Small PA Jr, Boykins LG, and Wright PF: Role of IgA versus IgG in the control of influenza viral infection in the murine respiratory tract. J Immunol 2004;173:1978-1986.

34. Rosztoczy I, Sweet C, Toms GL, and Smith H: Replication of influenza virus in organ cultures of human and simian urogenital tissues and human foetal tissues. Br J Exp Pathol 1975;56:322-328.

35. Russell MW, and Kilian M: Biological activities of IgA. In Mestecky J, Bienenstock J, Lamm ME, Mayer L, McGhee JR, and Strober W, eds. Mucosal Immunology, 3rd ed. Elsevier Academic Press, Burlington, MA, 2005, pp. 267-290.

36. Skirrow SZ, and BonDurant RH: Immunoglobulin isotype of specific antibodies in reproductive tract secretions and sera in Trichomonas foetus infected heifers. Am J Vet Res 1990;51:645-653.

37. Staudt LM, and Gerhard W: Generation of antibody diversity in the immune response of BALB/c mice to influenza virus hemagglutinin. I. Significant variation in repertoire expression between individual mice. $\mathrm{J}$ Exp Med 1983;157:687-704.

38. Sullivan DA, and Wira CR: Hormonal regulation of immunoglobulins in the rat uterus: Uterine response to a single estradiol treatment. Endocrinology 1983;112:260-268. 
39. Sweet C, Collie MH, Toms GL, and Smith H: The pregnant guinea pig as a model for studying influenza virus infection in utero: Infection of foetal tissues in organ culture and in vivo. Br J Exp Pathol 1977;58:133-139.

40. Sweet C, Toms GL, and Smith H: The pregnant ferret as a model for studying the congenital effects of influenza virus infection in utero: Infection of foetal tissues in organ culture and in vivo. Br J Exp Pathol 1977;58:113-123.

41. Tamura S, Funato H, Hirabayashi Y, Kikuta K, Suzuki Y, Nagamine T, Aizawa C, Nakagawa M, and Kurata T: Functional role of respiratory tract hemagglutinin-specific $\operatorname{IgA}$ antibodies in protection against influenza. Vaccine 1990; 8:479-485.

42. Tamura S, Funato H, Hirabayashi Y, Suzuki Y, Nagamine $\mathrm{T}$, Aizawa C, and Kurata T: Cross-protection against influenza A virus infection by passively transferred respiratory tract $\operatorname{IgA}$ antibodies to different hemagglutinin molecules. Eur J Immunol 1991;21:1337-1344.

43. VanCott TC, Kaminski RW, Mascola JR, Kalyanaraman VS, Wassef NM, Alving CR, Ulrich JT, Lowell GH, and Birx DL: HIV-1 neutralizing antibodies in the genital and respiratory tracts of mice intranasally immunized with oligomeric gp160. J Immunol 1998;160:2000-2012.

44. Wilschut J, de Haan A, Geerligs HJ, Huchshorn JP, van Scharrenburg GLM, Palache AM, Renegar KB, and Small PA Jr: Liposomes as a mucosal adjuvant system: An intranasal liposomal influenza subunit vaccine and the role of IgA in nasal anti-influenza immunity. $\underline{\mathrm{J} \text { Liposome Res }}$ 1994;4:301-314.

45. Winner L III, Mack J, Weltzin R, Mekalanos JJ, Kraehenbuhl J-P, and Neutra MR: New model for analysis of mucosal immunity: Intestinal secretion of specific monoclonal immunoglobulin A from hybridoma tumors protects against Vibrio cholerae infection. Infect Immun 1991;59:977-982.

46. Wira CR, Sullivan DA, and Sandoe CP: Epithelial cell involvement in the estradiol-stimulated accumulation of $\operatorname{IgA}$ in the rat uterus. J Steroid Biochem 1983;19:469-474.

47. Wyde PR, Six HR, Ambrose MW, and Throop BJ: Influenza virus infection and bacterial clearance in young, adult, or aged mice. J Gerontol Biol Sci 1989;44:B118-B124.

48. Yetter RA, Lehrer S, Ramphal R, Barber WH, and Small PA Jr: Outcome of influenza infection: Effect of site of initial infection and heterotypic immunity. Infect Immun 1980;29:654-662.

Address reprint requests to: Dr. Kathryn B. Renegar 131 Fraker Road Buffalo, MO 65622

E-mail: renegar38125@go.com

Received June 10, 2006; accepted August 5, 2006. 